\title{
EVALUASI PENATAUSAHAAN ASET TETAP PEMERINTAH KOTA PADANG
}

\author{
Rasyidah Mustika \\ Jurusan Akuntansi, Politeknik Negeri Padang
}

\begin{abstract}
This research aims to evaluate the suitability of fixed assets on government administration of Padang city concerning the administration by Permendagri 17 on 2007 and the constraints of fixed assets in the administration of the Padang City. This research is a case study with a descriptive analysis techniques. Data collection techniques are by interview, observation and documentation. The evaluation is to evaluate the implementation of fixed asset accounting, fixed asset inventory, fixed asset reporting, and completeness of filling fixed asset documents. The result shown that the administration of fixed assets of Padang City have not achieve yet the degree of compliance in about $100 \%$, because the average both evaluation of the accounting, inventory, reporting and completeness of the filling documents produced the degree of conformity in about by $62 \%$ or categorized as suitable category of Permendagri No. 17 on 2007. Un-maximum implementation of the government administration of Padang city is because there are many obstacles in the administration, such as limited data that support the fixed assets, socialization of the administration of the assets that is still weak, the limitation of human resources, and lack of adequate compensation for the welfare of employees in the field of assets administration.
\end{abstract}

\section{Keywords: Evaluation, Administration of Fixed Assets, Technical Management, Region's Property.}

\section{PENDAHULUAN}

Penyajian aset tetap sangat signifikan dalam neraca, karena salah satu poin penting yang harus tergambar dalam neraca adalah aset tetap. Oleh sebab itu, keakuratan data aset tetap tentunya dibutuhkan dalam mendukung laporan keuangan agar dapat tersaji secara wajar, karena selama ini banyak opini yg dikeluarkan oleh Badan Pemeriksa Keuangan (BPK) masih menyoroti masalah aset tetap. Neraca daerah yang merupakan bagian dari laporan keuangan akan lengkap dan dapat dipercaya jika penatausahaan aset antara fisik aset, dokumen kepemilikan, dan penatausahaan dalam buku inventaris mempunyai kesesuaian. Dengan adanya alur penatausahaan yang sistematis, maka tingkat kepercayaan terhadap proses penatausahaan akan selalu dapat dipercaya siapapun yang membaca laporan keuangan tersebut (Yusuf, 2010).

Berdasarkan Peraturan Pemerintah Nomor 38 Tahun 2008, hasil dari penatausahaan aset/barang milik daerah yang merupakan bagian dari pengelolaan aset/barang milik daerah dimanfaatkan dalam rangka: a).
Penyusunan neraca pemerintah daerah setiap tahun; b). Perencanaan kebutuhan pengadaan dan pemeliharaan barang milik daerah setiap tahun, untuk digunakan sebagai bahan penyusunan rencana anggaran; c). Pengamanan administratif terhadap barang milik daerah. Aset tetap yang dimiliki sebagai akibat dari adanya belanja modal merupakan syarat utama dalam memberikan pelayanan publik. Seperti kita ketahui tugas utama instansi pemerintah adalah memberikan pelayanan kepada publik, jadi aset tetap merupakan hal yang penting bagi suatu instansi pemerintah.

Ketidaktertiban administrasi dalam pelaksanaan prosedur penatausahaan aset/barang milik daerah yang meliputi pembukuan, inventarisasi dan pelaporan, menyebabkan pemerintah daerah kesulitan untuk mengetahui secara pasti aset yang dikuasai/dikelolanya, sehingga aset-aset yang dikelola pemerintah daerah cenderung tidak optimal dalam penggunaannya, serta disisi lain pemerintah daerah akan mengalami kesulitan untuk mengembangkan 
pemanfatan aset pada masa yang akan datang.

Menurut Kepala DPKA Kota Padang (dalam Indowarta, 2009) Dinas Pengelolaan Keuangan dan Aset (DPKA) Kota Padang terpaksa melakukan inventarisir aset sebanyak dua kali pada tahun 2009. Selain itu opini yang di berikan oleh Badan Pemeriksa Keuangan (BPK) atas audit Laporan Keuangan Pemerintah Daerah Kota Padang, selama tiga tahun terakhir yaitu wajar dengan pengecualian. Pemberian opini ini tidak terlepas dari permasalahan aset tetap yang belum tertata dengan baik. Pengecualian pada opini BPK untuk LKPD tahun anggaran 2009, menyatakan bahwa nilai aset gedung dan bangunan sekolah pada Dinas Pendidikan sebesar Rp. 5.829.555.883,00 tidak diyakini kewajarannya karena tidak memuat seluruh nilai gedung dan bangunan sekolah yang berasal dari dana selain APBD serta tidak didukung dengan dokumen yang memadai.

Dari adanya indikasi belum optimalnya penatausahaan aset/barang milik daerah, menyebabkan pemerintah daerah kesulitan untuk mengetahui secara pasti aset yang dikuasai/dikelolanya, sehingga aset-aset yang dikelola pemerintah daerah cenderung tidak optimal dalam penggunaannya, serta disisi lain pemerintah daerah akan mengalami kesulitan untuk mengembangkan pemanfatan aset pada masa yang akan datang. Hal ini juga berpengaruh terhadap keakuratan nilai aset yang tersaji di neraca pemerintah daerah, padahal keakuratan nilai aset ini sangat mendukung dalam pemberian opini BPK. Melihat fakta yang terjadi, penulis tertarik untuk melakukan penelitian tentang pelaksanaan penatausahaan aset tetap pada Pemerintah Kota Padang. Dalam penelitian ini penulis akan mengevaluasi penatausahaan aset tetap di Pemerintah Kota Padang.

\section{Pertanyaan Penelitian}

Berdasarkan uraian permasalahan yang ada, maka masalah yang diteliti kemudian dirumuskan dalam pertanyaan penelitian sebagai berikut:

a. Seberapa besar tingkat kesesuaian penatausahaan aset tetap di Pemerintah Kota Padang, dibandingkan dengan penatausahaan berdasarkan Permendagri 17 Tahun 2007?

b. Apa saja kendala dalam penatausahaan aset tetap Pemerintah Kota Padang?
Batasan pada penelitian ini yaitu, penelitian ini hanya menggunakan 1 (satu) SKPD sebagai pihak pengguna yang dimiliki Pemerintah Kota Padang, yaitu Dinas Pendidikan Kota Padang, karena SKPD ini merupakan SKPD yang memiliki jumlah fisik aset tetap terbesar di Pemerintah Kota Padang.

\section{Tujuan Penelitian}

Berdasarkan uraian diatas penelitian ini bertujuan untuk:

a. Mengevaluasi seberapa besar tingkat kesesuaian penatausahaan aset tetap di Pemerintah Kota Padang dengan penatausahaan berdasarkan Permendagri 17 tahun 2007.

b. Menentukan dan menganalisis apa saja kendala dalam penatausahaan aset tetap Pemerintah Kota Padang.

\section{TINJAUAN PUSTAKA}

\section{Aset}

Berdasarkan Peraturan Pemerintah Nomor 24 Tahun 2005 tentang Standar akuntansi Pemerintahan dalam Pernyataan No. 07 paragraf 5 diuraikan dengan jelas tentang definisi aset, yaitu sumber daya ekonomi yang dikuasai dan/atau dimiliki olehpemerintah sebagai akibat dari peristiwa masa lalu dan dari mana manfaat ekonomidan/atau sosial di masa depan diharapkan dapat diperoleh, baik oleh pemerintah maupunmasyarakat, serta dapat diukur dalam satuan uang, termasuk sumber daya non keuanganyang diperlukan untuk penyediaan jasa bagi masyarakat umum dan sumbersumberdayayang dipelihara karena alasan sejarah dan budaya.

\section{Aset Tetap}

Aset Tetap menurut definisi yang dikeluarkan oleh Komite Standar Akuntansi Pemerintah yang ditulis dalam Buletin Teknis No. 01 adalah Aset berwujud yang mempunyai masa manfaat lebih dari 12 bulan untuk digunakan dalam kegiatan pemerintah atau dimanfaatkan oleh masyarakat umum yang terdiri atas tanah; peralatan dan mesin; gedung dan bangunan; jalan dan irigasi; dan jaringan; aset tetap lainnya dan konstruksi dalam pengerjaan.

\section{Batasan Penelitian}

62 Jurnal Akuntansi \& Manajemen Vol 10 No. 1 Juni 2015. ISSN 1858-3687 hal 61-71 


\section{Penatausahaan Aset/Barang Milik Daerah}

Menurut Peraturan Menteri Dalam Negeri No 17 Tahun 2007, penatausahaan adalah rangkaian kegiatan yang meliputi pembukuan, inventarisasi dan pelaporan aset/barang milik daerah sesuai dengan ketentuan yang berlaku. Apabila penatausahaan tidak sesuai dengan prosedur yang ada maka akan mengakibatkan laporan aset daerah tidak sinkron dengan laporan keuangan khususnya neraca pemerintah daerah tersebut.

Hasil penatausahaan barang milik daerah menurut Peraturan Pemerintah No. 38 Tahun 2008digunakan dalam rangka:

a. Penyusunan neraca pemerintah daerah setiap tahun

b. Perencanaan kebutuhan pengadaan dan pemeliharaan barang milik daerah setiap tahun, untuk digunakan sebagai bahan penyusunan rencana anggaran

c. Pengamanan administratif terhadap barang milik daerah

Dalam penatausahaan barang milik daerah/aset daerah dilakukan 3 kegiatan meliputi:

\subsection{Pembukuan}

Dalam Peraturan Menteri dalam Negeri No. 17 tahun 2007, pembukuan merupakan kegiatan pendaftaran dan pencatatan barang milik daerah ke dalam Daftar Barang Pengguna (DBP)/Daftar Barang kuasa Pengguna (DBKP) menurut penggolongan dan kodefikasi barang yang dilakukan oleh pengguna/kuasa pengguna barang. Pembukuan dimaksudkan agar semua BMD yang berada dalam penguasaan pengguna barang dan yang berada dalam pengelolaan pengelola barang tercatat dengan baik.

Dalam melakukan pendaftaran dan pencatatan pengguna/kuasa pengguna barang mengacu pada format, Kartu Inventaris Barang (KIB) A Tanah, Kartu Inventaris Barang (KIB) B Peralatan dan Mesin, Kartu Inventaris Barang (KIB) C Gedung dan Bangunan, Kartu Inventaris Barang (KIB) D Jalan, irigasi dan jaringan, Kartu Inventaris Barang (KIB) E Aset tetap lainnya, Kartu Inventaris Barang (KIB) F Konstruksi dalam pengerjaan, Kartu Inventaris Ruangan (KIR).

\subsection{Inventarisasi}

Menurut Permendagri 17 tahun 2007 inventarisasi merupakan kegiatan atau tindakan untuk melakukan perhitungan, pengurusan, penyelenggaraan, pengaturan, pencatatan data dan pelaporan BMD dalam unit pemakaian. Pelaksanaan inventaris dibagi dalam dua kegiatan yakni, pelaksanaan pencatatan dan pelaporan.

Menurut Siregar (2004) inventarisasi aset terdiri dari dua aspek yaitu inventarisasi fisik dan yuridis/legal. Aspek fisik terdiri dari bentuk, luas, lokasi, volume/jumlah, jenis, alamat dan lain-lain, sedangkan aspek yuridis adalah status penguasaan. Proses kerjanya adalah dengan melakukan pendaftaran labeling, cluster, secara administrasi sesuai dengan manajemen aset.

\subsection{Pelaporan}

Pelaporan Barang milik Daerah adalah salah satu sarana penyampaian informasi yang bagi penerimanya dapat digunakan untuk mengetahui tentang posisi dan kondisi Aset tetap, serta sejauh mana Aset Tetap tersebut telah dimanfaatkan untuk menunjang pelaksanaan tugas pokok dan fungsi instansi.

\section{RANCANGAN PENELITIAN}

Penelitian ini dilakukan dengan metode studi kasus, data evaluasi yang dikumpulkan melalui wawancara dan dokumentasi akan dianalisis serta dievaluasi berdasarkan kriteria yang ditentukan dengan menggunakan analisis deskriptif kualitatif.

\section{Jenis dan Sumber Data}

Data yang digunakan dalam penelitian ini adalah data primer yang diperoleh dari Dinas Pengelolaan Keuangan dan Aset Daerah Kota Padang(DPKAD), serta SKPD di lingkungan pemerintah Kota Padang yaitu Dinas Pendidikan Kota Padang,Lokasi penelitian ini terdapat di Pemerintah Kota Padang. Unit Analisis adalah Dinas Pengelola Keuangan dan Aset Daerah Kota Padang selaku PPKD, serta Dinas Pendidikan selaku SKPD yang ada di lingkungan pemerintah Kota Padang.

\section{Teknik Pengumpulan Data}

Teknik pengumpulan data yang digunakan peneliti dalam melakukan penelitian ini yaitu, wawancara, dokumentasi dan observasi.

\section{Teknik Analisis Data}

Teknik yang dipergunakan dalam 
penelitian ini adalah studi kasus dengan teknik analisis deskriptif. Untuk itu, evaluasi dan analisis yang dilakukan dapat memberikan suatu perbandingan (komparasi) kriteria dari penatausahaan aset tetap menurut Permendagri No 17 Tahun 2007 dengan penatausahaan aset tetap yang diterapkan di Pemerintah Kota Padang sebagai suatu realita yang akan diteliti.

\section{Prosedur Evaluasi Penatausahaan Aset Tetap}

Evaluasi dilakukan dengan cara membandingkan antara pelaksanaan penatausahaan Aset Tetap di Pemerintah Kota Padang dengan Permendagri Nomor 17 Tahun 2007, kemudian dilakukan penilaian dan dihitung dalam bentuk presentase sehingga akan dihasilkan indeks yang memberikan informasi tingkat kesesuaian prosedur penatausahaan aset tetap di Pemerintah Kota Padang dengan peraturan perundangan yang berlaku. Jadi, indeks dalam penelitan ini merupakan angka yang menunjukkan perbandingan kriteria-kriteria yang ditetapkan berdasarkan peraturan perundangan.

Penilaiannya adalah sebagai berikut jika kriteria sesuai dengan fakta yang terjadi dilapangan (ada/ya) maka diberi skor 1 (satu), jika kriteria belum sesuai(tidak ada/tidak) maka diberi skor 0 (nol) (Ritonga, 2010).

\section{Evaluasi Penatausahaan Aset Tetap Pemerintah Kota Padang}

Evaluasi ini digunakan untuk menilai apakah pembukuan, inventarisasi dan pelaporan aset tetap pada pemerintah Kota Padang telah sesuai dengan peraturan perundangan yang berlaku.Evaluasi dihitung dengan menggunakan kriteria penilaian yang meliputi kriteria pelaksanaan penatausahaan aset tetap yaitu pelaksanaan pembukuan, inventarisasi dan pelaporan aset tetap serta evaluasi kelengkapan pengisian dokumen dalam penatausahaan ini. Adapun Kriteria yang ditetapkan untuk masing-masing evaluasi berdasarkan pada permendagri 17 tahun 2007. Dalam hal pelaksanaan pembukuan aset tetap penulis menetapkan 20 kriteria dengan nilai maksimal sebesar 20, untuk kegiatan inventarisasi penulis menetapkan 25 kriteria dengan nilai maksimal 25, serta untuk kegiatan pelaporan aset tetap penulis menetapkan 23 kriteria dengan nilai maksimal 23.

Kelengkapan pengisian dokumen terdiri dari 6 jenis dokumen yang dijadikan dasar dalam penatausahaan aset tetap berdasarkan pada permendagri 17 tahun 2007. Masingmasing dokumen memiliki kriteria yang berbeda.Masing-masing dokumen di evaluasi berdasarkan kelengkapan pengisian dokumen tersebut berdasarkan kriteria yang ditetapkan. Kelengkapan pengisian dokumen untuk Kartu Inventaris Barang (Tanah) terdiri dari 11 kriteria, Kartu Inventaris Barang (Mesin dan Peralatan) terdiri dari 8 kriteria, Kartu Inventaris Barang (Gedung dan Bangunan) terdiri dari 13 kriteria, Kartu Inventaris Barang (Jalan, Irigasi dan jaringan) terdiri dari 11 kriteria, Kartu Inventaris Barang (Aset Tetap lainnya) terdiri dari 7 kriteria, Kartu Inventaris Barang (Konstruksi Dalam pengerjaan) terdiri dari 11 kriteria.

\section{Menghitung Tingkat Kesesuaian Penatausahaan Aset Tetap}

Tingkat kesesuaian dalam evaluasi ini dihitung dengan menggunakan teknik deskriptif presentase yaitu teknik analisis dengan membuat presentase dari data yang ada, kemudian dideskripsikan. Penghitungannya sebagai berikut: total nilai yang diperoleh dibagi dengan total kriteria dikali seratus persen (Ritonga, 2010).

Tingkat Kesesuaian $=($ Total nilai yang diperoleh/Total kriteria) x $100 \%$

Selanjutnya akan dilakukan penilaian dari tingkat kesesuaian yang didapat secara keseluruhan (overall), maka dalam penelitian ini menggunakan kriteria kesesuaian sebagai berikut (Widyaningrum dan Hapsari, 2010):

- Jika memiliki kesesuaian $\quad 81-100 \%$ : Sangat Sesuai

- Jika memiliki kesesuaian $\quad 61-80 \%$ : Sesuai

- Jika memiliki kesesuaian $\quad 41-60 \%$ : Cukup Sesuai

- Jika memiliki kesesuaian $21-40 \%$. : Tidak Sesuai

- Jika memiliki kesesuaian $\quad 0-20 \%$ : Sangat Tidak Sesuai

\section{PEMAPARAN TEMUAN DAN ANALISIS} HASIL STUDI KASUS

1. Kesesuaian Penatausahaan Aset Tetap Pemerintah Kota Padang dengan Permendagri 17 Tahun 2007 


\subsection{Evaluasi Pembukuan, Inventarisasi dan Pelaporan Aset Tetap}

Tabel 1

Evaluasi Pembukuan, Inventarisasi dan Pelaporan Aset Tetap

\begin{tabular}{|c|l|c|c|c|}
\hline No & $\begin{array}{c}\text { Aspek yang } \\
\text { di evaluasi }\end{array}$ & $\begin{array}{c}\text { Total } \\
\text { Skor }\end{array}$ & $\begin{array}{c}\text { Skor } \\
\text { Maksimal }\end{array}$ & $\begin{array}{c}\text { Perse } \\
\text { ntase }\end{array}$ \\
\hline 1 & $\begin{array}{l}\text { Pembukuan } \\
\text { Aset Tetap }\end{array}$ & 16 & 20 & $80 \%$ \\
\hline 2 & $\begin{array}{l}\text { Inventarisas } \\
\text { i Aset Tetap }\end{array}$ & 13 & 25 & $52 \%$ \\
\hline 3 & $\begin{array}{l}\text { Pelaporan } \\
\text { Aset Tetap }\end{array}$ & 15 & 23 & $65 \%$ \\
\hline & Rata-rata & & & $66 \%$ \\
\hline
\end{tabular}

Sumber: Pengolahan data

Berdasarkan hasil perhitungan persentase untuk pembukuan aset tetap diperoleh hasil bahwa tingkat kesesuaiannya sebesar $80,0 \%$ atau termasuk kategori sesuai dengan Peraturan Menteri Dalam Negeri Nomor 17 Tahun 2007. Bila ditelusuri lagi hal ini karena pemerintah Kota Padang telah mengimplementasikan 16 kriteria dari 20 kriteria yang ditetapkan untuk kegiatan pelaksanaan pembukuan aset tetap berdasarkan permendagri 17 tahun 2007. Sementara itu, masih ada 4 kriteria lagi yang yang belum terlaksana dengan baik oleh Pemerintah Kota Padang, di Dinas Pendidikan Kota Padang, yaitu dokumen kepemilikin selain tanah dan/atau bangunan tidak disimpan oleh SKPD selaku pengguna barang, Pengisian KIB oleh pengurus barang belum lengkap dan benar, Kartu Inventaris Ruangan tidak menggambarkan semua aset tetap yang ada pada masing-masing ruangan, Pengurus barang tidak melakukan koordinasi dengan pembantu pengelola(bidang aset) dalam pencatatan dan pendaftaran barang milik daerah di KIB ke dalam Daftar Barang Milik Daerah (DBMD) tepat waktu.

Berdasarkan hasil perhitungan persentase untuk inventarisasi aset tetap diperoleh hasil bahwa tingkat kesesuaiannya sebesar $52,0 \%$ atau termasuk kategori cukup sesuai dengan Peraturan Menteri Dalam Negeri Nomor 17 Tahun 2007. Hasil evaluasi yang didapatkan, bahwa kegiatan inventarisasi di Pemerintah Kota Padang belum melaksanakan semua kriteria yang ditetapkan dalam kegiatan inventarisasi ini, masih ada 12 kriteria yang belum dilaksanakan oleh Pemerintah Kota Padang yaitu, diantaranya SKPD tidak membuat Buku Inventaris barang yang menunjukkan semua kekayaan daerah yang yang bersifat kebendaan, baik bergerak maupun yang tidak bergerak, serta yang meliputi lokasi, jenis/merk type, jumlah, ukuran, harga, tahun pembelian, asal barang, keadaan barang dsb, pelaksanaan sensus barang milik daerah yang dilaksanakan pada akhir tahun 2008 tidak menghasilkan laporan sensus barang milik daerah.

Berdasarkan hasil perhitungan persentase untuk pelaporan aset tetap diperoleh hasil bahwa tingkat kesesuaiannya sebesar $65,2 \%$ atau termasuk kategori sesuai dengan Peraturan Menteri Dalam Negeri Nomor 17 Tahun 2007. Pemerintah Kota Padang telah mengimplementasikan 15 kriteria dari 23 kriteria yang ditetapkan. Sementara itu, masih ada beberapa kriteria yang tidak diimplementasikan dalam kegiatan pelaporan ini, diantaranya SKPD tidak memiliki laporan mutasi barang semesteran, hal ini menyebabkan pengguna/SKPD tidak dapat melaporkan barang semesteran kepada pembantu pengelola barang, karena mutasi barang bertambah atau berkurang pada SKPD setiap semester tidak dicatat pada laporan mutasi barang. Laporan aset tetap yang dibuat oleh pembantu pengelola masih belum memiliki kelengkapan data, tidak semua aset tetap yang ada di laporan aset tetap milik daerah dapat dipertanggungjawabkan keberadaannya, serta masih adanya perbedaan data antara laporan aset tetap yang dibuat oleh pembantu pengelola dan laporan dari SKPD.

Evaluasi pembukuan, inventarisasi, dan pelaporan, memiliki total skor rata - rata sebesar $66 \%$.dimana tingkat kesesuaian masing-masing kegiatan berbeda, jika dilihat dari hasil perhitungan berdasarkan tabel 5.1 kegiatan pembukuan mencapai tingkat kesesuaian sebesar $80 \%$, kegiatan inventarisasi sebesar $52 \%$, sementara itu kegiatan pelaporan sebesar $65,2 \%$. Hasil penilaian dari masing-masing kriteria untuk kegiatan pembukuan, inventarisasi dan pelaporan dapat dilihat secara lebih jelas, pada tabel dibawah ini:

Tabel 2

Evaluasi Pembukuan, Inventarisasi dan Pelaporan Aset Tetap

\begin{tabular}{|c|c|c|c|}
\hline No & \multicolumn{2}{|c|}{ Aspek yang di Evaluasi (Kriteria) } & Skor \\
\hline 1 & \multicolumn{3}{|c|}{ Pembukuan Aset Tetap } \\
\hline & 1 & $\begin{array}{l}\text { SKPD memiliki Daftar } \\
\text { Barang Pengguna } \\
\text { (DBP)/daftar aset SKPD }\end{array}$ & 1 \\
\hline
\end{tabular}




\begin{tabular}{|c|c|c|}
\hline 2 & $\begin{array}{l}\text { Pengurus barang melakukan } \\
\text { pendaftaran dan pencatatan } \\
\text { barang milik daerah ke } \\
\text { dalam Daftar Barang } \\
\text { Pengguna (DBP)/daf1tar } \\
\text { aset SKPD }\end{array}$ & 1 \\
\hline 3 & $\begin{array}{l}\text { SKPD melakukan } \\
\text { pendaftaran dan pencatatan } \\
\text { aset ke dalam Daftar Barang } \\
\text { Pengguna(DBP)/daftar aset } \\
\text { SKPD menurut } \\
\text { penggolongan dan kodefikasi } \\
\text { barang. }\end{array}$ & 1 \\
\hline 4 & $\begin{array}{l}\text { Dokumen kepemilikan selain } \\
\text { tanah dan/atau bangunan } \\
\text { disimpan oleh SKPD selaku } \\
\text { pengguna barang }\end{array}$ & 0 \\
\hline 5 & $\begin{array}{l}\text { SKPD memiliki Kartu } \\
\text { Inventaris Barang (KIB). }\end{array}$ & 1 \\
\hline 6 & $\begin{array}{l}\text { SKPD memiliki Kartu } \\
\text { Inventaris Ruangan (KIR) }\end{array}$ & 1 \\
\hline 7 & $\begin{array}{l}\text { SKPD memiliki Daftar } \\
\text { Barang Pengguna } \\
\text { (DBP)/daftar aset SKPD }\end{array}$ & 1 \\
\hline 8 & $\begin{array}{l}\text { Pengurus barang melakukan } \\
\text { pendaftaran dan pencatatan } \\
\text { sesuai format Kartu } \\
\text { Inventaris Barang (KIB) A } \\
\text { untuk tanah }\end{array}$ & 1 \\
\hline 9 & $\begin{array}{l}\text { Pengurus barang melakukan } \\
\text { pendaftaran dan pencatatan } \\
\text { sesuai format Kartu } \\
\text { Inventaris Barang (KIB) B } \\
\text { untuk Peralatan dan Mesin }\end{array}$ & 1 \\
\hline 10 & $\begin{array}{l}\text { Pengurus barang melakukan } \\
\text { pendaftaran dan pencatatan } \\
\text { sesuai format Kartu } \\
\text { Inventaris Barang (KIB) C } \\
\text { untuk gedung dan bangunan }\end{array}$ & 1 \\
\hline 11 & $\begin{array}{l}\text { Pengurus barang melakukan } \\
\text { pendaftaran dan pencatatan } \\
\text { sesuai format Kartu } \\
\text { Inventaris Barang (KIB) D } \\
\text { untuk Jalan, Jaringan dan } \\
\text { irigasi }\end{array}$ & 1 \\
\hline 12 & $\begin{array}{l}\text { Pengurus barang melakukan } \\
\text { pendaftaran dan pencatatan } \\
\text { sesuai format Kartu } \\
\text { Inventaris Barang (KIB) E } \\
\text { untuk aset tetap lainnya }\end{array}$ & 1 \\
\hline 13 & $\begin{array}{l}\text { Pengurus barang melakukan } \\
\text { pendaftaran dan pencatatan } \\
\text { sesuai format Kartu } \\
\text { Inventaris Barang (KIB) F } \\
\text { untuk Konstruksi dalam } \\
\text { Pengerjaan }\end{array}$ & 0 \\
\hline 14 & $\begin{array}{l}\text { Pengisian KIB oleh pengurus } \\
\text { barang sudah lengkap dan } \\
\text { benar }\end{array}$ & 1 \\
\hline 15 & $\begin{array}{l}\text { Pengurus barang melakukan } \\
\text { pendaftaran dan pencatatan } \\
\text { sesuai format Kartu } \\
\text { Inventaris Ruangan (KIR) }\end{array}$ & 0 \\
\hline 16 & $\begin{array}{l}\text { Kartu Inventaris Ruangan } \\
\text { menggambarkan semua aset } \\
\text { tetap yang ada pada masing- } \\
\text { masing ruangan }\end{array}$ & 1 \\
\hline
\end{tabular}

\begin{tabular}{|c|c|c|c|}
\hline & 17 & $\begin{array}{l}\text { Pengurus barang melakukan } \\
\text { koordinasi dengan pembantu } \\
\text { pengelola(bidang aset) } \\
\text { dalam pencatatan dan } \\
\text { pendaftaran barang milik } \\
\text { daerah di KIB ke dalam } \\
\text { Daftar Barang Milik Daerah } \\
\text { (DBMD) tepat waktu }\end{array}$ & 0 \\
\hline & 18 & $\begin{array}{l}\text { Pembantu Pengelola (bidang } \\
\text { aset) memiliki Rekapitulasi } \\
\text { Kartu Inventaris Barang } \\
\text { (KIB). }\end{array}$ & 1 \\
\hline & 19 & $\begin{array}{l}\text { Dokumen kepemilikan } \\
\text { barang daerah berupa tanah } \\
\text { dan/atau bangunan dsimpan } \\
\text { oleh pengelola }\end{array}$ & 1 \\
\hline & 20 & $\begin{array}{l}\text { Pembantu Pengelola (bidang } \\
\text { aset) melakukan pendaftaran } \\
\text { dan pencatatan BMD } \\
\text { menurut penggolongan } \\
\text { barang dan kodefikasi } \\
\text { barang. }\end{array}$ & 1 \\
\hline & \multicolumn{2}{|c|}{ Total Skor } & 16 \\
\hline & \multicolumn{2}{|c|}{ Persentase } & $80,0 \%$ \\
\hline \multirow[t]{10}{*}{ II } & \multicolumn{3}{|c|}{ Pelaksanaan Inventarisasi Aset Tetap } \\
\hline & 1 & $\begin{array}{l}\text { SKPD/pengguna barang } \\
\text { melakukan inventarisasi } \\
\text { barang yang dicatat di dalam } \\
\text { Kartu Inventaris Barang dan } \\
\text { Kartu Inventaris Ruangan } \\
\text { secara kolektif. }\end{array}$ & 1 \\
\hline & 2 & $\begin{array}{l}\text { Setiap barang inventaris milik } \\
\text { daerah (Aset) diberikan } \\
\text { kodefikasi untuk } \\
\text { mengamankan dan } \\
\text { menjelaskan status } \\
\text { kepemilikan pada masing- } \\
\text { masing pengguna/SKPD }\end{array}$ & 1 \\
\hline & 3 & $\begin{array}{l}\text { SKPD memiliki Buku } \\
\text { Inventaris barang yang } \\
\text { menunjukkan semua } \\
\text { kekayaan daerah yang yang } \\
\text { bersifat kebendaan, baik } \\
\text { bergerak maupun yang tidak } \\
\text { bergerak }\end{array}$ & 0 \\
\hline & 4 & $\begin{array}{l}\text { Buku Inventaris meliputi } \\
\text { lokasi, jenis/merk type, } \\
\text { jumlah, ukuran, harga, tahun } \\
\text { pembelian, asal barang, } \\
\text { keadaan barang dsb }\end{array}$ & 0 \\
\hline & 5 & $\begin{array}{l}\text { Kartu Inventaris Ruangan } \\
\text { dipasang disetiap ruangan } \\
\text { kerja }\end{array}$ & 1 \\
\hline & 6 & $\begin{array}{l}\text { Pengguna barang } \\
\text { menghimpun KIB dan KIR } \\
\text { dan mencatatnya dalam } \\
\text { buku inventaris }\end{array}$ & 0 \\
\hline & 7 & $\begin{array}{l}\text { Pengguna melaporkan buku } \\
\text { inventaris ke pembantu } \\
\text { pengelola (bagian aset) } \\
\text { diakhir tahun anggaran }\end{array}$ & 0 \\
\hline & 8 & $\begin{array}{l}\text { Pembantu Pengelola (bidang } \\
\text { aset) memiliki Rekapitulasi } \\
\text { Buku Inventaris yang } \\
\text { lengkap }\end{array}$ & 0 \\
\hline & 9 & $\begin{array}{l}\text { Pembantu Pengelola (bidang } \\
\text { aset) memiliki Buku Induk } \\
\text { Inventaris }\end{array}$ & 1 \\
\hline
\end{tabular}

66 Jurnal Akuntansi \& Manajemen Vol 10 No. 1 Juni 2015. ISSN 1858-3687 hal 61-71 


\begin{tabular}{|c|c|c|}
\hline 10 & $\begin{array}{l}\text { Pembantu pengelola barang } \\
\text { mengkompilasi Buku } \\
\text { Inventaris menjadi buku } \\
\text { induk inventaris }\end{array}$ & 1 \\
\hline 11 & $\begin{array}{l}\text { Rekapitulasi Buku Induk } \\
\text { Inventaris ditandatangani } \\
\text { oleh pengelola atau } \\
\text { pembantu pengelola }\end{array}$ & 1 \\
\hline 12 & $\begin{array}{l}\text { Daftar Rekapitulasi inventaris } \\
\text { disusun oleh pembantu } \\
\text { pengelola dengan } \\
\text { menggunakan bahan dari } \\
\text { rekapitulasi inventaris barang } \\
\text { yang disampaikan oleh } \\
\text { pengguna/SKPD }\end{array}$ & 1 \\
\hline 13 & $\begin{array}{l}\text { Pembantu Pengelola } \\
\text { melakukan sensus barang } \\
\text { milik daerah sekurang- } \\
\text { kurangnya sekali dalam lima } \\
\text { tahun }\end{array}$ & 1 \\
\hline 14 & $\begin{array}{l}\text { Pelaksanaan sensus barang } \\
\text { milik daerah menghasilkan } \\
\text { laporan sensus barang milik } \\
\text { daerah }\end{array}$ & 0 \\
\hline 15 & $\begin{array}{l}\text { Pembentukan Panitia } \\
\text { Sensus Barang Daerah; }\end{array}$ & 1 \\
\hline 16 & $\begin{array}{l}\text { Penataran Petugas } \\
\text { Pelaksanaan Sensus } \\
\text { Barang Provinsi/ } \\
\text { Kabupaten/Kota } \\
\text { dilaksanakan pada masing- } \\
\text { masing Daerah }\end{array}$ & 1 \\
\hline 17 & $\begin{array}{l}\text { Menyediakan } \\
\text { Kartu/Formulir/Buku Petunjuk } \\
\text { Pelaksanaan serta peralatan } \\
\text { yang diperlukan. }\end{array}$ & 1 \\
\hline 18 & $\begin{array}{l}\text { Menyiapkan biaya persiapan } \\
\text { dan pelaksanaan Sensus } \\
\text { Barang Daerah }\end{array}$ & 1 \\
\hline 19 & $\begin{array}{l}\text { Penyampaian formulir dan } \\
\text { bahan sampai unit kerja } \\
\text { terendah; }\end{array}$ & 1 \\
\hline 20 & $\begin{array}{l}\text { Melaksanakan sensus } \\
\text { barang daerah yang } \\
\text { masing masing di } \\
\text { SKPD/wilayah dengan } \\
\text { mengisi KIB dan KIR; }\end{array}$ & 0 \\
\hline 21 & $\begin{array}{l}\text { Penyelesaian hasil sensus } \\
\text { barang milik daerah dengan } \\
\text { menyampaikan buku } \\
\text { inventaris oleh unit kerja } \\
\text { terendah kepada atasan }\end{array}$ & 0 \\
\hline 22 & $\begin{array}{l}\text { Pembuatan Daftar } \\
\text { Rekapitulasi oleh Satuan } \\
\text { Kerja }\end{array}$ & 0 \\
\hline 23 & $\begin{array}{l}\text { Mengawasi dan } \\
\text { mengevaluasi hasil sensus } \\
\text { barang dalam SKPD }\end{array}$ & 0 \\
\hline 20 & $\begin{array}{l}\text { Melaksanakan sensus } \\
\text { barang daerah yang } \\
\text { masing masing di } \\
\text { SKPD/wilayah dengan } \\
\text { mengisi KIB dan KIR; }\end{array}$ & 0 \\
\hline 24 & $\begin{array}{l}\text { Membuat Buku Induk } \\
\text { Inventaris }\end{array}$ & 0 \\
\hline 25 & $\begin{array}{l}\text { Melaporkan hasil sensus } \\
\text { barang milik daerah kepada } \\
\text { Departemen Dalam Negeri. }\end{array}$ & 0 \\
\hline \multicolumn{2}{|c|}{ Total Skor } & 13 \\
\hline \multicolumn{2}{|c|}{ Persentase } & $52,0 \%$ \\
\hline
\end{tabular}

\begin{tabular}{|c|c|c|c|}
\hline \multirow[t]{2}{*}{ III } & \multicolumn{3}{|c|}{ Pelaksanaan Pelaporan Aset Tetap } \\
\hline & 1 & $\begin{array}{l}\text { SKPD memiliki Laporan } \\
\text { Mutasi Barang semesteran }\end{array}$ & 0 \\
\hline & 2 & $\begin{array}{l}\text { SKPD memiliki Daftar Mutasi } \\
\text { Barang tahunan }\end{array}$ & 1 \\
\hline & 3 & $\begin{array}{l}\text { SKPD memiliki Rekapitulasi } \\
\text { Daftar Mutasi Barang }\end{array}$ & 1 \\
\hline & 4 & $\begin{array}{l}\text { SKPD memiliki Daftar Usulan } \\
\text { Barang yang Akan Dihapus }\end{array}$ & 1 \\
\hline & 5 & $\begin{array}{l}\text { Pengguna/Kuasa pengguna } \\
\text { barang sudah membuat dan } \\
\text { menyampaikan laporan atas } \\
\text { mutasi barang kepada } \\
\text { pembantu pengelola barang }\end{array}$ & 1 \\
\hline & 6 & $\begin{array}{l}\text { Daftar mutasi barang yang } \\
\text { dilaporkan oleh } \\
\text { Pengguna/Kuasa pengguna } \\
\text { barang sudah menjelaskan } \\
\text { alasan penyebab bertambah } \\
\text { dan berkurangnya barang } \\
\text { milik daerah/aset tetap }\end{array}$ & 1 \\
\hline & 7 & $\begin{array}{l}\text { Penguna/Kuasa Pengguna } \\
\text { Barang menyampaikan } \\
\text { laporan pengguna barang } \\
\text { semesteran, tahunan, dan } 5 \\
\text { (lima) tahunan kepada } \\
\text { pengelola BMD melalui } \\
\text { pembantu pengelola BMD }\end{array}$ & 0 \\
\hline & 8 & $\begin{array}{l}\text { Mutasi barang bertambah } \\
\text { dan/atau berkurang pada } \\
\text { SKPD setiap semester, } \\
\text { dicatat secara tertib pada } \\
\text { Laporan Mutasi Barang }\end{array}$ & 0 \\
\hline & 9 & $\begin{array}{l}\text { Mutasi barang bertambah } \\
\text { dan/atau berkurang pada } \\
\text { SKPD setiap tahun, dicatat } \\
\text { secara tertib pada Daftar } \\
\text { Mutasi Barang }\end{array}$ & 1 \\
\hline & 10 & $\begin{array}{l}\text { Pembantu Pengelola (bidang } \\
\text { aset) memiliki Laporan } \\
\text { Barang Milik Daerah (LBMD). }\end{array}$ & 1 \\
\hline & 11 & $\begin{array}{l}\text { Pembantu Pengelola (bidang } \\
\text { aset) memiliki Rekapitulasi } \\
\text { Laporan Mutasi Barang }\end{array}$ & 0 \\
\hline & 12 & $\begin{array}{l}\text { Pembantu Pengelola (bidang } \\
\text { aset) memiliki Rekapitulasi } \\
\text { Daftar Mutasi Barang }\end{array}$ & 1 \\
\hline & 13 & $\begin{array}{l}\text { Pembantu Pengelola (bidang } \\
\text { aset) memiliki Rekapitulasi } \\
\text { Daftar Usulan Barang yang } \\
\text { Akan Dihapus }\end{array}$ & 1 \\
\hline & 14 & $\begin{array}{l}\text { Pelaporan BMD memiliki } \\
\text { kelengkapan data dan } \\
\text { ditandatangani oleh pejabat } \\
\text { yang berwenang }\end{array}$ & 0 \\
\hline & 15 & $\begin{array}{l}\text { Organisasi Pengelolaan } \\
\text { BMD mengetahui BMD yang } \\
\text { dikelolanya melalui laporan } \\
\text { yang dibuat oleh pengurus, } \\
\text { kuasa pengguna, pengguna, } \\
\text { pembantu pengelola dan } \\
\text { pengelola. }\end{array}$ & 1 \\
\hline & 16 & $\begin{array}{l}\text { Pembantu Pengelola (bidang } \\
\text { aset) memiliki Rekapitulasi } \\
\text { Daftar Barang Milik Daerah } \\
\text { (DBMD). }\end{array}$ & 1 \\
\hline & 17 & $\begin{array}{l}\text { BMD dalam LBMD dapat } \\
\text { dipertangungjawabkan } \\
\text { keberadaannya }\end{array}$ & 0 \\
\hline & 18 & Pelaporan BMD tepat waktu & 0 \\
\hline
\end{tabular}




\begin{tabular}{|c|c|c|c|}
\hline & 19 & $\begin{array}{l}\text { Pelaporan BMD yang dibuat } \\
\text { oleh pembantu pengelola } \\
\text { tidak memiliki perbedaan } \\
\text { dengan laporan BMD yang } \\
\text { lainnya. }\end{array}$ & 0 \\
\hline & 20 & $\begin{array}{l}\text { Laporan yang dibuat oleh } \\
\text { pengelola memiliki dasar } \\
\text { yang kuat dan jelas dalam } \\
\text { penentuan biaya atau nilai } \\
\text { sebuah BMD }\end{array}$ & 1 \\
\hline & 21 & $\begin{array}{l}\text { Laporan BMD atau Buku } \\
\text { Induk Inventaris dapat } \\
\text { dipahami oleh semua pihak } \\
\text { yang membutuhkan } \\
\text { informasi mengenai BMD. }\end{array}$ & 1 \\
\hline & 22 & $\begin{array}{l}\text { BMD dalam LBMD dapat } \\
\text { dipertangungjawabkan } \\
\text { keberadaannya }\end{array}$ & 1 \\
\hline & 23 & $\begin{array}{l}\text { Laporan Barang Milik Daerah } \\
\text { (LBMD) digunakan sebagai } \\
\text { bahan untuk menyusun } \\
\text { neraca pemerintah daerah }\end{array}$ & 1 \\
\hline & \multicolumn{2}{|c|}{ Total Skor } & 15 \\
\hline & \multicolumn{2}{|c|}{ Persentase } & $65,2 \%$ \\
\hline \multicolumn{3}{|c|}{ Rata-Rata Persentase } & $66,1 \%$ \\
\hline
\end{tabular}

\subsection{Evaluasi Kelengkapan Pengisian Dokumen Penatausahaan Aset Tetap}

Evaluasi ini dilakukan dengan cara menilai kelengkapan pengisian dokumen Kartu Inventaris Barang, yang merupakan dasar dalam penatausahaan aset tetap. Apabila kartu inventarisasi ini diisi dengan lengkap oleh pengurus barang sesuai dengan keadaan aset tetap yang sebenarnya, maka pihak-pihak yang berkepentingan akan dengan mudah untuk memantau keberadaan aset tetap tersebut, dan tidak akan ada lagi aset tetap yang tidak diakui kewajarannya atas opini yang dikeluarkan oleh BPK.

Tabel 3

Evaluasi Kelengkapan Pengisian Kartu Inventaris Barang

\begin{tabular}{|c|l|c|}
\hline No & \multicolumn{1}{|c|}{$\begin{array}{l}\text { Jenis Kartu Inventaris } \\
\text { Barang (KIB) }\end{array}$} & Persentase \\
\hline 1 & KIB Tanah & $77 \%$ \\
\hline 2 & KIB Mesin dan Peralatan & $62 \%$ \\
\hline 3 & $\begin{array}{l}\text { (KIB) Gedung dan } \\
\text { Bangunan }\end{array}$ & $72 \%$ \\
\hline 4 & $\begin{array}{l}\text { (KIB) Jalan, Irigasi dan } \\
\text { Jaringan }\end{array}$ & $36 \%$ \\
\hline 5 & (KIB) Aset Tetap lainnya & $49 \%$ \\
\hline 6 & $\begin{array}{l}\text { (KIB) Konstruksi Dalam } \\
\text { Pengerjaan }\end{array}$ & $42 \%$ \\
\hline & Rata-rata & $\mathbf{5 8 \%}$ \\
\hline
\end{tabular}

68 Jurnal Akuntansi \& Manajemen Vol 10 No. 1 Juni 2015. ISSN 1858-3687 hal 61-71 1.2.1 Kartu Inventaris Barang (KIB) Tanah
(10 kriteria)

Berdasarkan hasil perhitungan persentase untuk kelengkapan pengisian Kartu Inventarisasi Barang Tanah diperoleh hasil bahwa tingkat kesesuaiannya sebesar $77 \%$ atau termasuk kategori sesuai dengan Peraturan Menteri Dalam Negeri Nomor 17 Tahun 2007. Masih adanya ketidaklengkapan dalam pengisian KIB tanah ini yaitu, ketidaklengkapan dalam pengisian keterangan nomor dan tanggal sertifikat tanah sebesar $97 \%$, ketidaklengkapan dalam pengisian keterangan penggunaan tanah sebesar $43 \%$, ketidaklengkapan dalam pengisian keterangan tahun pengadaan tanah sebesar $30 \%$, serta ketidaklengkapan pengisian keterangan status tanah sebesar $23 \%$.

1.2.2 Kartu Inventaris Barang (KIB) Mesin dan Peralatan (8 kriteria)

Berdasarkan hasil perhitungan persentase untuk kelengkapan pengisian Kartu Inventarisasi Barang Mesin dan Peralatan diperoleh hasil bahwa tingkat kesesuaiannya sebesar $62 \%$ atau termasuk kategori sesuai dengan Peraturan Menteri Dalam Negeri Nomor 17 Tahun 2007. Dalam pengisian kartu inventaris barang peralatan dan mesin, ketidaklengkapan pengisian keterangan ukuran barang, nomor pabrik/rangka dan mesin polisi/bpkb sebesar $100 \%$, serta ketidaklengkapan nomor register mesin dan peralatan.

\subsubsection{Kartu Inventaris Barang (KIB) Gedung dan Bangunan(13 kriteria)}

Berdasarkan hasil perhitungan persentase untuk kelengkapan pengisian Kartu Inventarisasi Barang Gedung dan Bangunan diperoleh hasil bahwa tingkat kesesuaiannya sebesar $72 \%$ atau termasuk kategori sesuai dengan Peraturan Menteri Dalam Negeri Nomor 17 Tahun 2007. Masih adanya ketidaklengkapan dalam pengisian KIB gedung dan bangunan ini yaitu, ketidaklengkapan dalam pengisian keterangan nomor dan tanggal dan nomor dokumen gedung serta keterangan luas tanah dari bangunan sebesar 100\%, ketidaklengkapan dalampengisian keterangan kondisi bangunan sebesar $30 \%$, 
ketidaklengkapan dalam pengisian letak atau lokasi bangunan sebesar $30 \%$, serta untuk status dari tanah bangunan memiliki ketidaklengkapan pengisian sebesar $23 \%$.

1.2.4 Kartu Inventaris Barang (KIB) Jalan, Irigasi dan Jaringan (11 kriteria)

Berdasarkan hasil perhitungan persentase untuk kelengkapan pengisian Kartu Inventarisasi Jalan, Irigasi dan Jaringan diperoleh hasil bahwa tingkat kesesuaiannya sebesar $36 \%$ atau termasuk kategori tidak sesuai dengan Peraturan Menteri Dalam Negeri Nomor 17 Tahun 2007. Bila ditelusuri untuk kelengkapan pengisian KIB ini, masih banyak item kriteria yang tidak lengkap, dari semua item aset tetap, tidak satupun yang ada keterangan nomor kode barang, nomor register barang, keterangan konstruksi dan ukuran dari jalan, irigasi dan jaringan, keterangan dokumen dari jalan, irigasi dan jaringan, serta status dan kode tanah atas jalan, irigasi dan bangunan.

\subsubsection{Kartu Inventaris Barang (KIB) Aset Tetap lainnya (7 kriteria)}

Berdasarkan hasil perhitungan persentase untuk kelengkapan pengisian Kartu Inventarisasi Aset Tetap lainnya diperoleh hasil bahwa tingkat kesesuaiannya sebesar $48,6 \%$ atau termasuk kategori cukup sesuai sesuai dengan Peraturan Menteri Dalam Negeri Nomor 17 Tahun 2007. Masih adanya ketidaklengkapan dalam pegisian KIB ini yaitu, tidak adanya keterangan spesifiasi barang, ketidaklengkapan dalam pengisian keterangan asal perolehan barang sebesar $70 \%$, ketidaklengkapan dalam pengisian keterangan tahun cetak/pembelian sebesar $63 \%$, serta ketidaklengkapan keterangan jumlah barang sebesar $60 \%$.

\subsubsection{Kartu Inventaris Barang (KIB) Konstruksi} Dalam Pengerjaan (11 kriteria)

Berdasarkan hasil perhitungan persentase untuk kelengkapan pengisian Kartu Inventarisasi Konstruksi Dalam Pengerjaan diperoleh hasil bahwa tingkat kesesuaiannya sebesar $42 \%$ atau termasuk kategori cukup sesuai dengan Peraturan Menteri Dalam Negeri Nomor 17 Tahun 2007. Dalam pengisian kartu inventaris konstruksi dalam pengerjaan, masih banyak item kriteria yang tidak diisi oleh pengirus barang, dari semua item aset tetap, tidak satupun yang ada keterangan fisik bangunan KDP, luas dari bangunan KDP, keterangan tanggal dan nomor dokumen kontrak, keterangan tanggal, bulan dan tahun dimulainya pekerjaan, serta keterangan status dank ode tanah dari tanah bangunan Konstruksi Dalam Pengerjaan.

Tabel 4

Evaluasi Penatausahaan Aset Tetap Pemerintah Kota Padang

\begin{tabular}{|c|l|c|c|}
\hline No & \multicolumn{1}{|c|}{$\begin{array}{c}\text { Aspek yang di } \\
\text { evaluasi }\end{array}$} & $\begin{array}{c}\text { Persenta } \\
\text { se }\end{array}$ & $\begin{array}{c}\text { Tingkat } \\
\text { Kesesuaian }\end{array}$ \\
\hline 1 & $\begin{array}{l}\text { Pembukuan, } \\
\text { Inventarisasi dan } \\
\text { Pelaporan }\end{array}$ & $66 \%$ & Sesuai \\
\hline 2 & $\begin{array}{l}\text { Evaluasi } \\
\text { Kelengkapan } \\
\begin{array}{l}\text { Pengisian } \\
\text { Dokumen KIB }\end{array}\end{array}$ & $58 \%$ & Cukup Sesuai \\
\hline & Rata-rata & $62 \%$ & Sesuai \\
\hline
\end{tabular}

Dari hasil perhitungan berdasarkan tabel 4, evaluasi kelengkapan pengisian dokumen penatausahaan aset tetap di Pemerintah Kota Padangdiperoleh hasil bahwa tingkat kesesuaiannya sebesar $58 \%$ atau termasuk kategori cukup sesuai. Hal ini menunjukkan bahwa Pemerintah Kota Padang belum sepenuhnya melaksanakan Permendagri No.17 tahun 2007.

Secara keseluruhan rata - rata hasil evaluasi terhadap penatausahaan aset tetap belum ada yang dapat mencapai derajat kesesuaian sebesar $100 \%$, karena rata - rata baik pembukuan, inventarisasi, pelaporan serta kelengkapan pengisian dokumen penatausahaan aset tetap hanya menghasilkan tingkat kesesuaian sebesar $62 \%$ atau termasuk kategori sesuai dengan permendagri 17 tahun 2007.

\section{Kendala-Kendala Dalam Penata- usahaan Aset Tetap}

\subsection{Keterbatasan data pendukung aset tetap}

Data pendukung aset tetap merupakan penunjang agar data aset yang disajikan di laporan aset dapat dipertanggungjawabkan keberadaannya, pengurus barang masih kesulitan dalam mendapatkan informasi/data tentang dokumen (tanggal dan nomor kontrak), tahun pembelian/perolehan serta harga atas barang/aset tetap tersebut. Dalam pelaksanakan penatausahaan aset tetap di pemerintah kota padang dalam mengisi format KIB dan KIR masih ditemukan kekurangan yang disebabkan sulitnya memperoleh dokumen atas aset tetap milik 
daerah yang sudah lama dan tidak jelas statusnya.

\subsection{Sosialisasi peraturan tentang penatausahaan aset masih lemah}

Kurangnya sosialisasi peraturan berupa program atau kegiatan seperti pendidikan, pelatihan, atau bimbingan teknis bagi para pengurus barang terhadap teknis penatausahaan aset tetap tersebut, menyebabkan pengurus barang memiliki keterbatasan dalam teknis pelaksanaan penatausahaan aset tersebut.

\subsection{Keterbatasan Sumber Daya Manusia}

Sumber daya manusia sebagai salah satu unsur penting di dalam pelaksanaan penatausaan aset tetap sangat berpengaruh terhadap hasil dari pelaksanaan penatausahaan aset tetap tersebut. Menurut sekretaris dinas pendidikan, pengurus barang di dinas pendidikan tidak mahir mengoperasikan komputer, jadi pada saat melakukan penginputan data ke dalam komputer pengurus barang mengalami kesulitan. Hal ini menjadi kendala dalam penatausahaan aset tetap, karena masih rendahnya sumberdaya pengurus barang.

\subsection{Kurangnya Kompensansi Yang Memadai Terhadap Kesejahteraan Pegawai Di Bidang Penatausahaan Aset Tetap.}

Dalam menjalankan tugas sebagai pejabat fungsional kompensasi yang memadai sangat dibutuhkan agar dapat menjalankan pekerjaan dengan penuh tanggung jawab, untuk itu dibutuhkan motivasi yang kuat dalam diri seorang pengurus barang. Di Pemerintah Kota Padang honor pengurus barang hanya 150.000 perbulan, pengurus barang tidak diberi fasilitas dari skpd, hal ini juga menyebabkan pengurus barang terkendala dalam mengurusi barang.

\section{KESIMPULAN DAN SARAN}

\section{Kesimpulan}

Berdasarkan hasil pemaparan temuan dan analisis hasil studi kasus terhadap evaluasi penatausahaan aset tetap Pemerintah Kota Padang, peneliti menyimpulkan, antara lain :
1. Pemerintah Kota Padang telah melaksanakan penatausahaan aset tetap

sesuai dengan peraturan perundangundangan yang berlaku yaitu permendagri nomor 17 tahun 2007 tentang pedoman teknis pengelolaan barang milik daerah. Dari hasil observasi, evaluasi penatausahaan aset tetap memperoleh nilai sebesar $62 \%$. Sementara itu, untuk setiap prosedur penatausahaan aset tetap pada Pemerintah Kota Padang memperoleh nilai sebesar : (a) $80 \%$ untuk evaluasi kegiatan pembukuan aset tetap, (b) $52 \%$ untuk evaluasi kegiatan inventarisasi aset tetap, (c) 65\% untuk evaluasi kegiatan pelaporan aset tetap, (d) $58 \%$ untuk evaluasikelengkapan pengisian dokumen penatausahaan aset tetap.

2. Dalam melaksanakan penatausahaan aset tetap, kendala yang ditemui oleh Pemerintah Kota Padang yaitu: keterbatasan data pendukung aset tetap, sosialisasi peraturan tentang penatausahaan aset masih lemah, keterbatasan Sumber Daya Manusia, kurangnya kompensansi yang memadai terhadap kesejahteraan pegawai di bidang penatausahaan aset.

\section{Saran}

Saran yang dapat diberikan dari penelitian ini adalah Pemerintah Kota Padang hendaknya segera memperbaiki atau menyelesaikan kekurangan-kekurangan yang terdapat di dalam pelaksanaan penatausahaan barang milik daerah barang milik daerah. Apabila kekurangan yang ada telah diperbaiki, maka penatausahaan barang milik daerah akan dapat memiliki peran penting di dalam mendukung pengelolaan barang milik daerah yang efektif dan efisien. Peningkatan kualitas terhadap Sumber Daya Manusia pelaksana pembukuan, inventarisasi, pelaporan barang milik daerah perlu diupayakan dalam bentuk pendidikan, pelatihan, atau bimbingan teknis, aparat yang bertugas dalam pengelolaan barang milik daerah harus memiliki kesamaan pemahaman agar terbina sistem dan mekanisme pengelola barang yang baik di tiap-tiap SKPD.

Pemerintah Kota Padang sebaiknya juga menerapkan aplikasi pengelolaan barang milik daerah yang di dalamnnya tercakup pentausahaan aset tetap melalui Sistem 
Informasi Manajemen Barang Daerah (SIMBADA). Hal ini dilakukan untuk mempercepat perolehan informasi mengenai inventarisasi barang milik daerah dan untuk mendapatkan data barang milik daerah yang benar dan lebih akurat (up to date).

\section{DAFTAR PUSTAKA}

Cooper, Donald R. dan Pamela S. Schindler. Metode Riset Bisnis. Vol.2, Edisi 9, Jakarta : PT. Media Global Edukasi.

Gie, Liang the. 2009. Administrasi Perkantoran Moderen. Yogyakarta: Liberty.

Hartono, Jogianto. 2010. Metodologi Penelitian Bisnis. Yogyakarta: BPFE.

Hapsari, Indriati D. 2010, Evaluasi terhadap penatausahaan belanja hibah(studi kasus pada pemerintah kabupaten magelang). Thesis S2 Magister Akuntansi UGM (tidak dipublikasikan). Yogyakarta.

Republik Indonesia, Undang - undang No. 17 Tahun 2003 Tentang Keuangan Negara.

Republik Indonesia, Undang - undang No. 32 Tahun 2004 Tentang Pemerintahan Daerah.

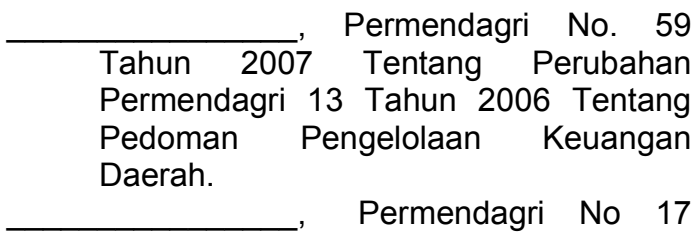
Tahun 2007 Tentang Pedoman Teknis Pengelolaan Barang Milik Daerah.

Peraturan Pemerintah No. 24 Tahun 2005 Tentang Standar Akuntansi Pemerintahan.

Peraturan Pemerintah No. 38 Tahun 2008 Tentang Perubahan Atas Peraturan Pemerintah No. 6 Tahun 2006 Tentang Pengelolaan Barang Milik Negara/Daerah.

Ritonga, Irwan. 2010. Reviu Laporan Keuangan Pemerintah Daerah. Yogyakarta: Lembaga Kajian Manajemen Pemerintah Daerah.

Sekaran, Umar. 2009. Research Methods for Business. Jakarta: Salemba Empat.

Siregar, Doli. 2004. Manejemen Aset. Jakarta: Gramedia Pustaka Utama.

Suhanda. 2007. Akuntansi Keuangan Pemerintahan Daerah. Padang: Andalas Lima Sisi.

Widyaningrum, Herlina. 2010,Evaluasi Prosedur Akuntansi Aset Tetap(Studi Kasus pada Dinas Pendidikan, Pemuda dan Olahraga Kabupaten Magelang TA 2009). Thesis S2 Magister Akuntansi UGM (tidak dipublikasikan). Yogyakarta.

Wirartha, Made I, 2006. Metodologi Penelitian Sosial Ekonomi, Yogyakarta: ANDI.

Yusuf, Muhammad. 2010, Delapan Langkah Pengelolaan Aset Daerah Menuju Pengelolaan Keuangan Daerah Terbaik, Salemba Empat, Jakarta.

http://www.indowarta.com/Data Kerusakan Aset Kota Padang Pasca Gempa Tidak Valid. (Diakses Senin, 22 Agustus 2011).

http://www.harianhaluan.com/ aporan Keuangan Daerah Masih Kacau.(Diakses Senin, 17 Oktober 2011. 